\title{
BMJ Open Smoking cessation care among patients with head and neck cancer: a systematic review
}

\author{
Kristen McCarter, ${ }^{1}$ Úrsula Martínez, ${ }^{2}$ Ben Britton, ${ }^{3}$ Amanda Baker, ${ }^{3}$ \\ Billie Bonevski, ${ }^{3}$ Gregory Carter, ${ }^{3}$ Alison Beck, ${ }^{3}$ Chris Wratten, ${ }^{3,4}$ \\ Ashleigh Guillaumier, ${ }^{3}$ Sean A Halpin, ${ }^{1}$ Luke Wolfenden ${ }^{3}$
}

To cite: McCarter K, Martínez Ú, Britton B, et al. Smoking cessation care among patients with head and neck cancer: a systematic review. BMJ Open 2016;6:e012296. doi:10.1136/bmjopen-2016012296

- Prepublication history and additional material is available. To view please visit the journal (http://dx.doi.org/ 10.1136/bmjopen-2016012296).

Received 14 April 2016 Revised 10 July 2016 Accepted 19 August 2016 CrossMark

${ }^{1}$ School of Psychology, The University of Newcastle, Callaghan, New South Wales, Australia

${ }^{2}$ Smoking Cessation and Addictive Disorders Unit, Department of Clinical Psychology and Psychobiology, University of Santiago de Compostela, Galicia, Spain

${ }^{3}$ School of Medicine \& Public Health, The University of Newcastle, Callaghan, New South Wales, Australia ${ }^{4}$ Department of Radiation Oncology, Calvary Mater Newcastle Hospital, Waratah New South Wales, Australia

Correspondence to Kristen McCarter; Kristen.McCarter@newcastle. edu.au

\section{ABSTRACT}

Objective: To examine the effectiveness of smoking cessation interventions in improving cessation rates and smoking related behaviour in patients with head and neck cancer (HNC).

Design: A systematic review of randomised and nonrandomised controlled trials.

Methods: We searched the following data sources: CENTRAL in the Cochrane Library, MEDLINE, EMBASE, PsycINFO and CINAHL up to February 2016. A search of reference lists of included studies and Google Scholar (first 200 citations published online between 2000 and February 2016) was also undertaken. The methodological quality of included studies was assessed using the Effective Public Health Practice Project Quality Assessment Tool (EPHPP). 2 study authors independently screened and extracted data with disagreements resolved via consensus.

Results: Of the 5167 studies identified, 3 were eligible and included in the review. Trial designs of included studies were 2 randomised controlled trials and 1 non-randomised controlled trial. 2 studies received a weak methodological rating and 1 received a moderate methodological rating. The trials examine the impact of the following interventions: (1) nurse delivered cognitive-behaviour therapy (CBT) via telephone and accompanied by a workbook, combined with pharmacotherapy; (2) nurse and physician brief advice to quit and information booklets combined with pharmacotherapy; and (3) surgeon delivered enhanced advice to quit smoking augmented by booster sessions. Only the trial of the nurse delivered CBT and pharmacotherapy reported significant increases in smoking cessation rates. 1 study measured quit attempts and the other assessed consumption of cigarettes per day and readiness to change. There was no significant improvement in quit attempts or cigarettes smoked per day among patients in the intervention groups, relative to control.

Conclusions: There are very few studies evaluating the effectiveness of smoking cessation interventions that report results specific to the HNC population. The 3 trials identified reported equivocal findings. Extended CBT counselling coupled with pharmacotherapy may be effective.

Trial registration number: CRD42016016421.

\section{Strengths and limitations of this study}

- To the best of our knowledge, this is the first systematic review examining the effectiveness of smoking cessation interventions in improving cessation rates and smoking-related behaviour in patients with head and neck cancer.

- The quality of the studies included in this review were compromised by small sample sizes and reliance on self-reported outcomes of smoking cessation that were not biochemically verified in two of the three included studies.

- Varying interventions, outcomes and end points, and the limited number of studies precluded quantitative synthesis of the trial findings.

\section{INTRODUCTION}

Tobacco use is a key risk factor for head and neck cancer $(\mathrm{HNC})^{1}$ with more than $75 \%$ of these cancers attributable to the combination of tobacco and alcohol use. ${ }^{2}$ Human papilloma virus is another common cause of HNC and smoking in this group while not causative, has been shown to influence prognosis significantly. $^{3}$ At least one-third of patients with HNC continue to smoke after diagnosis. ${ }^{4-6}$ Continued smoking increases risk for other smoking-related diseases, second primary tumours, ${ }^{7}$ disease recurrence ${ }^{8}$ and reduced treatment efficacy, increases toxicity and side effects from radiotherapy ${ }^{5}$ and negatively affects overall survival. ${ }^{5}$ Approximately $10-12 \%$ of patients with HNC develop a new cancer in the head and neck region within 2-3 years after the first cancer diagnosis. ${ }^{10}$

In addition to the diverse health benefits of permanent smoking cessation, quitting can have more specific benefits for patients with a cancer diagnosis. A number of studies have reported improvements in the prognosis of patients with a cancer diagnosis following smoking cessation. ${ }^{5} 811{ }^{12}$ For example, quitting smoking among patients with locally 
advanced HNC has been associated with a twofold increase in complete response to radiation therapy. ${ }^{5}$ Abstinence from smoking in patients with cancer has also been associated with less pain, higher quality of life scores and better performance status. ${ }^{13}$ Furthermore, smoking abstinence following diagnosis reduces morbidity and mortality, ${ }^{5} 14$ particularly among those with smoking-related cancers such as HNC and those diagnosed with a curable disease. ${ }^{15}$

Systematic reviews of smoking cessation interventions in the general oncology population have found that highintensity, multicomponent interventions that include a combination of pharmacological and behavioural approaches are effective in improving cessation rates. ${ }^{16} 17$ However, no reviews of the effectiveness of smoking cessation interventions for patients with HNC exist. Patients with varying types of cancer have been found to respond differently to cessation treatment depending on the perceived relevance of patient tobacco use to the onset or recovery from cancer. ${ }^{18}$ Further, among patients with $\mathrm{HNC}$, the location of the malignancy and treatment can cause difficulty in eating, fatigue, mucositis, dry mouth and taste changes ${ }^{19}$ that may uniquely influence patient receptivity to some pharmacotherapy interventions such as nicotine gum and require a tailored approach to cessation treatment. In addition to smoking, alcohol use is a key risk factor for HNC and a substantial proportion continue to drink alcohol, with $\sim 16 \%$ continuing to drink at hazardous levels after diagnosis. ${ }^{40}$ Such comorbidities present further obstacles to smoking cessation in this population ${ }^{21}$ and therefore may warrant tailored treatment. Furthermore, research in this particular cancer population has characterised patients with HNC as a particularly vulnerable group, with many living alone and having a limited social network. ${ }^{22}$ These factors may also necessitate extra support for patients with HNC to quit smoking.

Given the importance of ceasing tobacco use among patients with $\mathrm{HNC}$ and the lack of guidance from previous systematic reviews regarding effective cessation treatment among this group, the primary aim of this review is to examine the effectiveness of smoking cessation interventions on smoking cessation rates in adult patients with HNC.

\section{METHODS}

This systematic review was performed in accordance with a predetermined protocol and is reported to be consistent with the Preferred Reporting Items for Systematic Reviews and Meta-Analysis (PRISMA) statement. ${ }^{23}$ The review was prospectively registered with PROSPERO (CRD42016016421).

\section{Eligibility criteria}

Study characteristics

Types of studies

Studies with the following study designs were considered for inclusion:

- Randomised controlled trials, including cluster randomised controlled trials;
- Staggered enrolment trials or stepped-wedged trials;

- Quasi-randomised trials;

- Quasi-experimental trials with comparison/control groups, including non-randomised pre-post (beforeafter) trials with one or more intervention and control groups, time-series/interrupted time-series trials (including multiple baseline trials) with independent control groups, preference trials and regression discontinuity trials;

- Natural experiment studies that have a comparison group.

Trials without parallel comparison or control groups were excluded. There was no restriction based on length of follow-up or the year of publication. Studies were limited to those published in English in peer-reviewed scientific journals. Comparison groups for included trials could include no intervention controls, 'usual' practice or alternative interventions.

\section{Participants}

Participants of included studies were adults diagnosed with HNC (including cancers of the nasopharynx, oropharynx, oral cavity, larynx and hypopharynx) and current smokers or those who had recently quit, due to the potential for relapse. There were no restrictions on type (eg, radiotherapy, surgery, chemotherapy) or stage (eg, pre, during, post) of treatment. Studies that examined a heterogeneous group of patients with cancer but did not report results specific to an HNC subgroup were excluded. Studies that examined smoking cessation for carers of patients with HNC were also excluded.

\section{Types of interventions}

Interventions that aimed to improve the smoking cessation outcomes of patients with HNC in whom part of the intervention was conducted in a healthcare setting (eg, clinics and hospitals) were included. Interventions could include psychosocial and behavioural (such as counselling, brief advice, referral, web-based information and behavioural support) and/or pharmacological components (medication, nicotine replacement therapy (NRT) ). Interventions targeting improvement of delivery of smoking cessation services were included only when data for changes in smoking outcomes of patients with HNC were also reported. Studies that reported on population-level public health interventions (such as mass media campaigns, taxation and restrictions on tobacco advertising) were excluded.

\section{Outcomes}

Primary outcome:

- To be included, trials needed to report a measure of smoking cessation. This could include point prevalence or continuous abstinence, or current smoking status. Smoking cessation could be assessed via selfreport (eg, interviews, questionnaires and surveys) or biochemical measures (eg, carbon monoxide or cotinine assessment). 
Secondary outcomes:

- While not an inclusion criterion, we extracted any additional measures of smoking behaviour reported in trials as a study outcome including consumption of cigarettes per day, level of nicotine dependence, quit attempts and stage of change. Such data may be obtained via self-report (eg, interviews, questionnaires and surveys) or other methods.

\section{Information sources}

\section{Electronic databases}

The following electronic databases were searched for potentially eligible studies published up to February 2016: the Cochrane Central Register of Controlled trials (CENTRAL) in the Cochrane Library, MEDLINE (from 1946), EMBASE (from 1947), PsycINFO (from 1806) and CINAHL (from 1937). The MEDLINE search strategy (see online supplementary appendix A) was adapted for other databases and included filters used in other systematic reviews for population (patients with HNC) and was based on the Cochrane Tobacco Addiction Group standard review terms for health behaviour (smoking cessation).

\section{Other sources}

Studies were also obtained from the following sources:

- Reference lists of included studies;

- A search of Google Scholar (published online between 2000 and February 2016-the first 200 citations were examined).

\section{Study selection}

The titles and abstracts retrieved by electronic searches were exported to reference management software (Endnote V.X6) to remove duplicates. References were exported to the online software tool Covidence for screening. One reviewer (UM) performed title and abstract screening. Two reviewers (KM and UM) then independently performed full-text screening, data extraction and quality assessment. Reasons for exclusion of full texts were recorded and documented in figure 1. Any discrepancies were resolved by discussion between the reviewers.

\section{Data extraction}

Two review authors (KM and UM) independently extracted data from the included trials using a prepiloted data extraction form that was developed based on recommendations from the Cochrane Handbook for Systematic Reviews of Interventions. ${ }^{24}$ Discrepancies between reviewers regarding data extraction were resolved by discussion and consensus. The characteristics of each study were extracted, including study design, setting, country, participants, gender, age, intervention characteristics and outcomes.

\section{Assessment of methodological quality}

Studies included in the review were assessed for methodological quality using the Effective Public Health Practice Project Quality Assessment Tool (EPHPP) for quantitative studies. ${ }^{25}$ This tool covers any quantitative study design, includes components of intervention integrity and was judged suitable for use in systematic reviews of effectiveness. ${ }^{24} 26$ Two review authors (KM and UM) independently assessed study quality and discrepancies were resolved through discussion. The EPHPP assesses six methodological dimensions: selection bias, study design, confounders, blinding, data collection methods, and withdrawals and dropouts. These domains are rated on a three-point scale (strong, moderate, weak) according to predefined criteria and procedures recommended for tool use, and then given an overall global rating. Those with no weak ratings were given an overall rating of strong, whereas those with one weak rating were given an overall rating of moderate and those with two or more weak ratings across the six domains were given an overall weak rating. Two additional methodological dimensions provided by the tool are intervention integrity and analyses and these were also completed by the reviewers.

\section{Data analysis}

\section{Summary measures}

We reported all statistically significant and non-significant outcomes. Owing to the clinical and methodological heterogeneity and the small number of studies included in the review, meta-analysis was not performed and the study findings were synthesised narratively.

\section{RESULTS}

\section{Search results}

Abstracts of 5167 citations were screened and the full text of 29 manuscripts was sought for further assessment against the review inclusion criteria (figure 1). Of these, four publications describing three trials were included in the review. 4152728

\section{Study characteristics}

A description of the trial characteristics of included studies is provided in table 1 . Included studies were published between 1991 and 2006. Two randomised controlled trials (RCTs) ${ }^{4} 15 \quad 28$ and one non-RCT ${ }^{27}$ were identified. All trials compared interventions with a usual care no intervention control. All three studies were conducted in the USA. The interventions employed in Gosselin et $a l^{27}$ and Gritz et $a l^{1528}$ targeted smoking cessation alone, whereas the study by Duffy et at targeted multiple risk behaviours of smoking, alcohol use and depression.

The follow-up periods varied from 1 to 12 months postintervention. All studies were multicentre and participants were recruited from clinics that provided care to patients with HNC. Interventions were delivered at the 


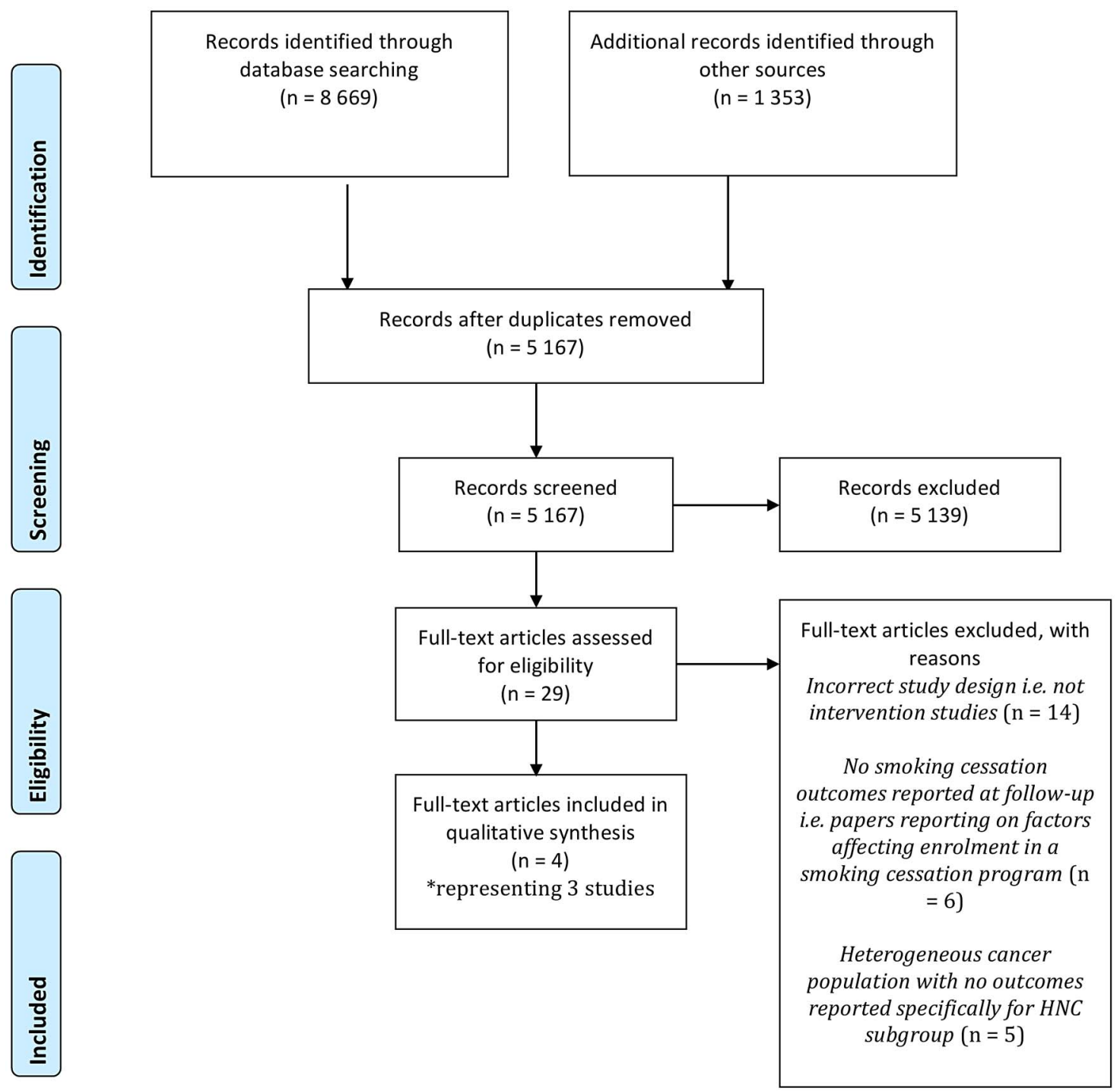

diagnosis/treatment stage of the cancer care continuum, including pretreatment to post-treatment. Two of the three studies reported the location of the HNC in participants. ${ }^{45}$ Only one study ${ }^{15}$ reported the type of cancer treatment patients received (radiation or surgery). Smoking cessation interventions were delivered by healthcare providers and were either nonpharmacological alone (cognitive-behaviour therapy (CBT), self-help material, telephone counselling) or combined with a pharmacological component (NRT, varenicline or bupropion; table 2). In all studies, the control group received usual care, ranging from information on the risks of continued smoking and the benefits of cessation, to handouts for resources, to referral for smoking cessation treatment.

\section{Methodological quality assessment}

Individual ratings for each study against the six methodological criteria and the assigned global rating are reported in table 3. Overall, two studies received a methodological quality rating of weak ${ }^{4} 27$ and one study received a rating of moderate. ${ }^{15}{ }^{28}$ Unrepresentative samples and non-reporting of blinding of participants and outcome assessors were key issues. Two studies relied solely on self-reported smoking status ${ }^{427}$ and one used urinary cotinine to confirm smoking status. ${ }^{15} 28$

The two additional methodological dimensions provided by the EPHPP tool, intervention integrity and analyses, were also completed. All three studies measured the percentage of participants who received the intervention as intended and were scored in the $80-100 \%$ category on this dimension. With regard to consistency of the interventions, Duffy et $a l^{t}$ did not describe whether the intervention was provided to all participants in the same way. Gosselin $e t a l^{7}$ reported that a proportion of the participants in the intervention condition had multiple clinic visits compared with the other intervention participants who had one visit. Gritz et $a l^{15} 28$ used exit checklists to ensure that their intervention was delivered consistently, with each component delivered to 


\begin{tabular}{|c|c|c|c|c|c|c|c|c|c|c|c|c|c|}
\hline \multirow{2}{*}{$\begin{array}{l}\begin{array}{l}\text { Author } \\
\text { year } \\
\text { (Ref) }\end{array} \\
\text { Duffy et al } \\
2006^{4}\end{array}$} & \multirow{2}{*}{$\begin{array}{l}\text { Study type } \\
\text { RCT }\end{array}$} & \multirow{2}{*}{$\begin{array}{l}\text { Study dates } \\
2000-2003\end{array}$} & \multirow{2}{*}{$\begin{array}{l}\text { Single-centre } \\
\text { or } \\
\text { multicentre } \\
\begin{array}{l}\text { Multi } \\
\text { (4 hospitals) }\end{array}\end{array}$} & \multirow[b]{2}{*}{$\begin{array}{l}\text { Setting } \\
\text { ENT clinic, } \\
\text { telephone. } 4 \\
\text { hospitals } \\
\text { including the } \\
\text { University of } \\
\text { Michigan } \\
\text { Medical Center } \\
\text { and } 3 \text { VA } \\
\text { hospitals in } \\
\text { Ann Arbor, MI, } \\
\text { Gainesville, FL, } \\
\text { and Dallas, TX }\end{array}$} & \multirow{2}{*}{$\frac{\text { Country }}{\text { USA }}$} & \multirow[b]{2}{*}{$\begin{array}{l}\text { Aim } \\
\text { To develop and } \\
\text { test a tailored } \\
\text { intervention for } \\
\text { patients with HNC } \\
\text { that included CBT, } \\
\text { nicotine } \\
\text { replacement } \\
\text { therapy, and } \\
\text { selective serotonin } \\
\text { reuptake inhibitor } \\
\text { management for } \\
\text { smoking, alcohol } \\
\text { use and } \\
\text { depression }\end{array}$} & \multirow[b]{2}{*}{$\begin{array}{l}\text { Inclusion criteria } \\
\text { Patients with HNC } \\
\text { from the time of } \\
\text { diagnosis and } \\
\text { thereafter who: } \\
\text { (1) screened } \\
\text { positive for } 1 \text { or } \\
\text { more of the } 3 \text { health } \\
\text { problems of } \\
\text { smoking, alcohol } \\
\text { and depression; (2) } \\
\text { were not pregnant; } \\
\text { and, (3) were } \\
>18 \text { years of age }\end{array}$} & \multirow{2}{*}{$\begin{array}{l}\begin{array}{l}\text { Number of } \\
\text { patients at } \\
\text { start of } \\
\text { intervention }\end{array} \\
184 \text { (91 UC; } \\
93 \text { I) }\end{array}$} & \multirow{2}{*}{$\begin{array}{l}\begin{array}{l}\text { Mean age } \\
\text { (years) }\end{array} \\
57 \text { years } \\
\text { (9.9 SD) }\end{array}$} & \multirow{2}{*}{$\begin{array}{l}\begin{array}{l}\text { Gender } \\
\text { M (\%) }\end{array} \\
84\end{array}$} & \multirow{2}{*}{$\begin{array}{l}\begin{array}{l}\text { Tumour } \\
\text { site/tumour } \\
\text { stage }\end{array} \\
\end{array}$} & \multicolumn{2}{|c|}{$\begin{array}{l}\text { Cancer treatment } \\
\text { type/stage of treatment }\end{array}$} \\
\hline & & & & & & & & & & & & $\begin{array}{l}\text { Larynx } 33 \% \text {, } \\
\text { oropharynx/ } \\
\text { hypopharynx } \\
30 \% \text {, oral } \\
\text { cavity/other } \\
37 \% \text { stage } 0 \text {, } \\
\text { I or II } 39 \% \text {, } \\
\text { stage III, IV } \\
61 \%\end{array}$ & $\begin{array}{l}\mathrm{NR} / \text { both new } \\
\text { and } \\
\text { post-treatment }\end{array}$ \\
\hline $\begin{array}{l}\text { Gosselin } \\
\text { et al } \\
2011^{27}\end{array}$ & $\begin{array}{l}\text { Quasi-experimental } \\
\text { design }\end{array}$ & $\begin{array}{l}\text { UC group } \\
\text { patients } \\
\text { recruited } \\
\text { between: } \\
\text { May } 2007 \\
\text { and June } \\
\text { 2007; EC } \\
\text { group } \\
\text { patients } \\
\text { recruited } \\
\text { between: } \\
\text { July 2007 } \\
\text { and August } \\
2007\end{array}$ & $\begin{array}{l}\text { Multi }(2 \\
\text { clinics) }\end{array}$ & $\begin{array}{l}\text { Dental/ } \\
\text { maxillofacial or } \\
\text { head and neck } \\
\text { clinic, } \\
\text { telephone. } \\
\text { Roswell Park } \\
\text { Cancer } \\
\text { Institute } \\
\text { (Buffalo, NY) }\end{array}$ & USA & $\begin{array}{l}\text { To evaluate the } \\
\text { effectiveness of a } \\
\text { brief staff training } \\
\text { programme on } \\
\text { improving the } \\
\text { delivery of tobacco } \\
\text { cessation services } \\
\text { to patients with } \\
\text { head and neck } \\
\text { cancers }\end{array}$ & $\begin{array}{l}\text { Current tobacco } \\
\text { users (ie, cigarettes, } \\
\text { cigar, pipe, } \\
\text { smokeless/chewing } \\
\text { tobacco or some } \\
\text { other type of } \\
\text { tobacco) }\end{array}$ & $\begin{array}{l}179(98 \mathrm{UC} \\
81 \mathrm{EC})\end{array}$ & $\begin{array}{l}55.8 \% \text { in } \\
53- \\
60 \text { years } \\
\text { quartile }\end{array}$ & 86.8 & & NR/NR & $\begin{array}{l}\mathrm{NR} / \text { new and } \\
\text { established } \\
\text { patients }\end{array}$ \\
\hline $\begin{array}{l}\text { Gritz et al } \\
(1993, \\
1991)^{1528}\end{array}$ & RCT & $\mathrm{NR}$ & $\begin{array}{l}\text { Multi (10 } \\
\text { clinics) }\end{array}$ & $\begin{array}{l}\text { Clinic. } \\
\text { Sites included } \\
3 \text { university } \\
\text { hospitals } \\
\text { (including both } \\
\text { the head and } \\
\text { neck and the } \\
\text { maxillofacial } \\
\text { clinics at } \\
\text { UCLA, the } \\
\text { main site), } 3 \\
\text { Veterans } \\
\text { Administration } \\
\text { medical } \\
\text { centres, } 2 \\
\text { county } \\
\text { hospitals, a } \\
\text { health } \\
\text { maintenance } \\
\text { organisation } \\
\text { hospital, and } \\
\text { an armed } \\
\text { services } \\
\text { hospital (CA) }\end{array}$ & USA & $\begin{array}{l}\text { Assess the efficacy } \\
\text { of a provider- } \\
\text { delivered smoking } \\
\text { cessation } \\
\text { intervention for } \\
\text { patients with head } \\
\text { and neck cancer }\end{array}$ & $\begin{array}{l}\text { Adult (over } 18 \text { years } \\
\text { of age) patients with } \\
\text { newly diagnosed } \\
\text { squamous cell } \\
\text { carcinomas of the } \\
\text { head and neck who } \\
\text { met the following } \\
\text { criteria: (1) life } \\
\text { expectancy of more } \\
\text { than } 1 \text { year; (2) } \\
\text { tobacco use within } \\
\text { the past year; (3) } \\
\text { absence of gross } \\
\text { psychopathology; } \\
\text { (4) medical } \\
\text { follow-up by local } \\
\text { providers; } \\
\text { (5) English } \\
\text { speaking and } \\
\text { reading; and } \\
\text { (6) agreement to } \\
\text { undergo treatment. }\end{array}$ & $\begin{array}{l}186 \text { (92 UC; } \\
94 \text { I) }\end{array}$ & 58.5 years & 73.7 & & $\begin{array}{l}\text { Oral } \\
\text { Tumours } \\
60.9 \% \text { (buccal } \\
\text { cavity } 54.9 \% ; \\
n=101 \text { and } \\
\text { pharynx } \\
6.0 \% ; n=11) \\
\text { and laryngeal } \\
39.1 \% \text { ( } n=72) / \\
\text { stages I and II } \\
31.1 \%(n=57) \text {, } \\
\text { stage III } \\
44.3 \%(n=81) \\
\text { and stage IV } \\
24.6 \%(n=45)\end{array}$ & $\begin{array}{l}\text { Radiation only } \\
28.5 \%(n=53) \text {, } \\
\text { total } \\
\text { laryngectomies } \\
24.7 \% \text { ( } n=46), \\
\text { surgeries other } \\
\text { than total } \\
\text { laryngectomy } \\
\text { which may have } \\
\text { been followed } \\
\text { by radiation } \\
46.8 \%(n=87) / \\
\text { spanned } \\
\text { pretreatment to } \\
\text { post-treatment }\end{array}$ \\
\hline
\end{tabular}


Table 2 Intervention description

\begin{tabular}{|c|c|c|c|}
\hline & \multicolumn{3}{|l|}{ Description } \\
\hline & \multicolumn{2}{|l|}{ Intervention } & \multirow[b]{2}{*}{ Control } \\
\hline & Non-pharmacological & Pharmacological & \\
\hline Duffy et al ${ }^{4}$ & $\begin{array}{l}\text { Nurse administered. CBT workbook, CBT telephone } \\
\text { counselling (9-11 sessions) }\end{array}$ & $\begin{array}{l}\text { Those who smoked were offered nicotine } \\
\text { replacement therapy and/or bupropion, and } \\
\text { those with depression were offered } \\
\text { antidepressants. }\end{array}$ & $\begin{array}{l}\text { Enhanced usual care; referred as needed for } \\
\text { smoking cessation, and/or alcohol treatment, } \\
\text { and/or psychiatric evaluation. Handout for local, } \\
\text { state and national resources tailored to each } \\
\text { study site }\end{array}$ \\
\hline Gosselin et $a^{P^{7}}$ & $\begin{array}{l}\text { Nurse and physician administered. Inquired about } \\
\text { tobacco use, advised patients to quit, and offered } \\
\text { assistance to tobacco users interested in quitting. } \\
\text { Information packets were made available for staff to } \\
\text { give to patients who reported current tobacco use. } \\
\text { Attempts to contact all patients by phone within } \\
10 \text { days of visiting the clinic were assigned to a } \\
\text { designated researcher who was trained in the delivery } \\
\text { of support and cessation counselling components at } \\
\text { the New York State Smokers Quitline. They were also } \\
\text { contacted } 1 \text { month after clinic visit. }\end{array}$ & $\begin{array}{l}\text { Prescription of stop smoking medication for } \\
\text { eligible patients; varenicline and bupropion }\end{array}$ & $\begin{array}{l}\text { Usual care; standard tobacco cessation } \\
\text { practices administered by health providers with } \\
\text { regard to asking patients about their tobacco } \\
\text { use status or providing assistance to quit } \\
\text { smoking at Roswell Park Cancer Institute }\end{array}$ \\
\hline Gritz et $a l^{1528}$ & $\begin{array}{l}\text { Delivered by head and neck surgeons or maxillofacial } \\
\text { prosthodontists. Enhanced initial advice } \\
\text { (supplemented the usual care advice with a discussion } \\
\text { of the participant's receptivity to quitting; a statement } \\
\text { of confidence in the participant's ability to stop; } \\
\text { presentation of } 3 \text { self-help booklets; a discussion of } \\
\text { tobacco withdrawal; a discussion to determine a target } \\
\text { quit date, including joint signature of the quit-smoking } \\
\text { contract; and an affirmation of continuing provider } \\
\text { support during follow-up care) session augmented by } \\
6 \text { booster sessions. }\end{array}$ & & $\begin{array}{l}\text { Usual care; standardised advice consisting of } \\
\text { information on the risks of continued smoking } \\
\text { and the benefits of cessation for patients with } \\
\text { head and neck cancer. No guidelines regarding } \\
\text { additional advice sessions; providers were free } \\
\text { to follow their usual practice regarding } \\
\text { discussing patient smoking practices. }\end{array}$ \\
\hline
\end{tabular}


Table 3 Ratings of methodological quality: strong, moderate and weak

\begin{tabular}{llllllll}
\hline & $\begin{array}{l}\text { Selection } \\
\text { bias }\end{array}$ & $\begin{array}{l}\text { Study } \\
\text { design }\end{array}$ & Confounders & Blinding & $\begin{array}{l}\text { Data } \\
\text { collection }\end{array}$ & Withdrawals & Global rating \\
\hline 1. Duffy et $a f^{4}$ & Weak & Strong & Strong & Moderate & Weak & Strong & Weak \\
2. Gosselin et $a f^{77}$ & Moderate & Strong & Weak & Moderate & Weak & Moderate & Weak \\
3. Gritz et $a l^{15} 28$ & Moderate & Strong & Strong & Weak & Strong & Moderate & Moderate \\
\hline
\end{tabular}

almost all participants in the intervention condition. However, since the health providers in this study gave advice in the control and intervention conditions, there was evidence that some contamination may have occurred. Both Duffy $e t a l^{4}$ and Gosselin et $a l^{27}$ used intent-to-treat analyses as appropriate.

\section{Effects of intervention}

Tables 3 and 4 describe the intervention characteristics and results of the included studies, respectively. All three included studies reported smoking cessation outcomes.

Duffy et $a t^{4}$ conducted an RCT to test a tailored smoking, alcohol and depression intervention in 184 patients with HNC recruited from four hospitals in the USA and conducted in ear, nose and throat clinics. The CBT intervention addressed smoking, alcohol and depression and used a workbook for patients and telephone counselling delivered by nurses in combination with NRT and/or bupropion (and antidepressants for depression) to target comorbid conditions (smoking, alcohol use and depression). The control group received enhanced usual care. The primary smoking cessation outcome in this study was self-reported smoking status (patients asked if they were currently smoking) measured at 6 months postintervention. The authors found that (for the 136 patients with HNC who smoked in the past 6 months at baseline) at 6-month follow-up, the intervention group reported significantly higher quit rates than those in the usual care group ( $47 \%$ vs $31 \%$, $\mathrm{p}<0.05)$. The authors did not measure any additional outcomes of smoking-related behaviour.

Gosselin et $a l^{27}$ conducted a study with a quasi-experimental design in 179 patients with $\mathrm{HNC}$ recruited from a dental/maxillofacial clinic and a head and neck clinic in the USA. The study compared the smoking behaviours of those who visited the clinic during a usual care phase (standard tobacco cessation practices) with those who visited the clinic during the intervention phase. The intervention phase employed nurse and physician brief advice to quit, information booklets and pharmacotherapy (varenicline and bupropion) during the clinic visit as well as a follow-up phone call within 10 days after the clinic visit to provide cessation counselling support. The primary smoking cessation outcome was self-reported smoking status (patients asked if they were currently smoking) at 1-month postintervention. The intervention was not effective in significantly increasing quit rates at 1-month follow-up with intention-to-treat (assumption that those lost to follow-up had all returned to smoking) quit rates $8 \%$ for the control group compared with $9 \%$ in the intervention group.

Gosselin et $a l^{27}$ also measured self-reported quit attempts (those who reported that they were currently smoking were subsequently asked whether or not they had made any attempt to stop smoking during the past month) at 1-month follow-up postintervention. No significant difference was found between intervention and control groups. No other smoking behaviours were reported.

Gritz et $a l^{1528}$ conducted an RCT to assess the efficacy of a provider delivered smoking cessation intervention compared with usual care advice in 186 patients with HNC recruited from 10 hospital or medical centre clinics in the USA. The intervention group received surgeon delivered enhanced advice (see table 3) to quit smoking augmented by six monthly booster sessions compared with a usual care control group. The authors reported three smoking cessation outcome measures: (1) ever quit (abstinent for 48 consecutive hours or longer at any time during the 12-month follow-up postintervention period after receiving initial smoking cessation advice); (2) point prevalence abstinence (abstinent for 48 hours or longer at the time of the 1-month, 6-month or 12-month follow-up interviews); and (3) continuous abstinence (abstinent at the 1-month, 6-month and 12-month interviews with no smoking at all after cessation). Cotinine validation of self-reported abstinence was also conducted at each follow-up point. No significant differences were found for any of the smoking cessation outcomes.

Gritz et $a l^{1528}$ also measured change in consumption of cigarettes per day from baseline at 12-month follow-up. Participants who were smoking at 12-month follow-up $(n=30)$ had significantly reduced their consumption during the study, from 25.4 cigarettes/day at baseline to 12.5 at 12 months $(p=0.0001)$. However, relative to the control group, such reductions were not significant. The study also reported readiness to stop using tobacco at baseline by questionnaire and classified according to the stage of change theory into four stages: precontemplator (not currently thinking about stopping smoking), contemplator (thinking of stopping within 1 year), action (quit within the past) and maintenance (quit for 6-12 months). The authors reported a relationship between cessation behaviours (at 12-month 


\begin{tabular}{|c|c|c|c|c|c|c|c|c|}
\hline \multirow[b]{2}{*}{$\begin{array}{l}\text { Author } \\
\text { year (Ref) }\end{array}$} & \multirow[b]{2}{*}{$\begin{array}{l}\text { Number of } \\
\text { patients at } \\
\text { start of } \\
\text { intervention }\end{array}$} & \multirow{2}{*}{$\begin{array}{l}\text { Current } \\
\text { smokers at } \\
\text { baseline; } \\
\text { outcome } \\
\text { measure }\end{array}$} & \multirow[b]{2}{*}{$\begin{array}{l}\text { Usual care } \\
\text { (number of } \\
\text { patients) at } \\
\text { follow-up }\end{array}$} & \multirow[b]{2}{*}{$\begin{array}{l}\text { Intervention } \\
\text { (number of } \\
\text { patients) at } \\
\text { follow-up }\end{array}$} & \multicolumn{2}{|l|}{ Primary outcome } & \multicolumn{2}{|l|}{ Secondary outcomes } \\
\hline & & & & & $\begin{array}{l}\text { Description and } \\
\text { follow-up interval }\end{array}$ & Results & $\begin{array}{l}\text { Description and } \\
\text { follow-up interval }\end{array}$ & Results \\
\hline $\begin{array}{l}\text { Duffy et al } \\
2006^{4}\end{array}$ & $\begin{array}{l}184 \text { (91 UC; } \\
93 \text { I) }\end{array}$ & $\begin{array}{l}148 \text { (68 UC; } 80 \\
\text { I); self-report } \\
\text { (smoked in the } \\
\text { past } 6 \text { months) }\end{array}$ & $\begin{array}{l}62 / 68(91 \\
\text { including } \\
\text { those not } \\
\text { 'smokers' at } \\
\text { baseline) }\end{array}$ & $\begin{array}{l}74 / 80 \text { ( } 93 \\
\text { including those } \\
\text { not 'smokers' } \\
\text { at baseline) }\end{array}$ & $\begin{array}{l}\text { Self-reported smoking } \\
\text { status (patients asked if } \\
\text { they were currently } \\
\text { smoking); } 6 \text { months } \\
\text { postintervention }\end{array}$ & $\begin{array}{l}\chi^{2} \text { tests of association } \\
\text { using ITT analysis: } \\
\text { significant difference in } \\
\text { smoking cessation } \\
\text { with } 47 \%(35 / 74) \\
\text { quitting in the } \\
\text { intervention group vs } \\
31 \%(19 / 62) \text { quitting in } \\
\text { the usual care group } \\
(p<0.05)\end{array}$ & $\begin{array}{l}\text { Subgroup analyses: } \\
\text { self-reported smoking } \\
\text { cessation rates; } 6 \text { months } \\
\text { postintervention }\end{array}$ & $\begin{array}{l}\text { Smoking cessation rates } \\
\text { for only those smokers with } \\
\text { comorbid depression and/ } \\
\text { or alcohol (omitting those } \\
\text { who smoked only; } n=101 \text { ); } \\
\text { the quit rates remained } \\
\text { higher in the intervention } \\
\text { group ( } 48 \% \text { ) compared } \\
\text { with the usual care group } \\
(26 \% ; p<0.05 \text { ). } \\
\text { All patients who smoked in } \\
\text { the past } 6 \text { months were } \\
\text { included as smokers and, } \\
\text { as expected, those who } \\
\text { smoked more recently } \\
\text { were significantly less likely } \\
\text { to quit in the enhanced } \\
\text { usual care and intervention } \\
\text { groups ( } p<0.001 \text { ). }\end{array}$ \\
\hline $\begin{array}{l}\text { Gosselin } \\
\text { et al } \\
2011^{27}\end{array}$ & $\begin{array}{l}179 \text { (98 UC; } \\
81 \mathrm{EC})\end{array}$ & $\begin{array}{l}179 \text { (98 UC; } 81 \\
\text { EC); self-report } \\
\text { current tobacco } \\
\text { use (105 } \\
\text { cigarettes, } 2 \\
\text { cigars, } 1 \text { pipe, } \\
1 \text { chew) }\end{array}$ & $60 / 98$ & $52 / 81$ & $\begin{array}{l}\text { Self-reported smoking } \\
\text { status (patients asked if } \\
\text { they were currently } \\
\text { smoking); } 1 \text {-month } \\
\text { postintervention }\end{array}$ & $\begin{array}{l}\chi^{2} \text { statistic was used to } \\
\text { evaluate differences } \\
\text { between the EC and } \\
\text { UC groups on smoking } \\
\text { behaviour reported. } \\
\text { Non-ITT quit rates } \\
\text { (assumption that those } \\
\text { lost to follow-up were } \\
\text { missing at random): } \\
\text { EC, } 14 \% \text { vs UC, 13\% } \\
\text { at } 1 \text { month (NS). } \\
\text { ITT quit rates } \\
\text { (assumption that those } \\
\text { lost to follow-up had all } \\
\text { returned to smoking): } \\
\text { EC, } 9 \% \text { vs UC, } 8 \% \text { at } \\
1 \text { month (NS) }\end{array}$ & $\begin{array}{l}\text { Self-reported quit attempt } \\
\text { (those who reported that } \\
\text { they were currently } \\
\text { smoking were } \\
\text { subsequently asked } \\
\text { whether or not they had } \\
\text { made any attempt to stop } \\
\text { smoking during the past } \\
\text { month); } 1 \text {-month } \\
\text { follow-up postintervention }\end{array}$ & $\begin{array}{l}\chi^{2} \text { statistic was used to } \\
\text { evaluate differences } \\
\text { between the EC and UC } \\
\text { groups on smoking } \\
\text { behaviour reported. Quit } \\
\text { attempts at } 1 \text {-month: I, } \\
56 \% \text { vs UC, } 55 \% \text { (NS) }\end{array}$ \\
\hline $\begin{array}{l}\text { Gritz et al } \\
(1993 \\
1991)^{1528}\end{array}$ & $\begin{array}{l}186 \text { (94 UC; } \\
92 \text { I) }\end{array}$ & $\begin{array}{l}164 \text {; self-report } \\
\text { (currently } \\
\text { smoking or } \\
\text { stopped } \\
\text { smoking }\end{array}$ & $56 / 92$ & $58 / 94$ & $\begin{array}{l}\text { Smoking cessation; ever } \\
\text { quit (abstinent for } 48 \\
\text { consecutive hours or } \\
\text { longer at any time during } \\
\text { the 12-month follow-up }\end{array}$ & $\begin{array}{l}\text { No significant } \\
\text { differences between } \\
\text { intervention and } \\
\text { control at any follow-up } \\
\text { on any of the } 3\end{array}$ & $\begin{array}{l}\text { Consumption of } \\
\text { cigarettes per day. Stage } \\
\text { of change; } 12 \text {-month } \\
\text { follow-up (for participants } \\
\text { who were current }\end{array}$ & $\begin{array}{l}\text { Participants who were } \\
\text { smoking at } 12 \text { month } \\
\text { follow-up }(n=30) \text { had } \\
\text { significantly reduced their } \\
\text { consumption during the }\end{array}$ \\
\hline
\end{tabular}




\begin{tabular}{|c|c|c|c|c|c|c|c|c|}
\hline \multirow[b]{2}{*}{$\begin{array}{l}\text { Author } \\
\text { year (Ref) }\end{array}$} & \multirow[b]{2}{*}{$\begin{array}{l}\text { Number of } \\
\text { patients at } \\
\text { start of } \\
\text { intervention }\end{array}$} & \multirow{2}{*}{$\begin{array}{l}\text { Current } \\
\text { smokers at } \\
\text { baseline; } \\
\text { outcome } \\
\text { measure }\end{array}$} & \multirow[b]{2}{*}{$\begin{array}{l}\text { Usual care } \\
\text { (number of } \\
\text { patients) at } \\
\text { follow-up }\end{array}$} & \multirow[b]{2}{*}{$\begin{array}{l}\text { Intervention } \\
\text { (number of } \\
\text { patients) at } \\
\text { follow-up }\end{array}$} & \multicolumn{2}{|l|}{ Primary outcome } & \multicolumn{2}{|l|}{ Secondary outcomes } \\
\hline & & & & & $\begin{array}{l}\text { Description and } \\
\text { follow-up interval }\end{array}$ & Results & $\begin{array}{l}\text { Description and } \\
\text { follow-up interval }\end{array}$ & Results \\
\hline & & $\begin{array}{l}<1 \text { month prior } \\
\text { to the baseline } \\
\text { interview }\end{array}$ & & & $\begin{array}{l}\text { postintervention period } \\
\text { after receiving initial } \\
\text { smoking cessation advice) } \\
\text { Point prevalence } \\
\text { abstinence (abstinent for } \\
48 \text { hours or longer at the } \\
\text { time of the follow-up } \\
\text { interview); } 1 \text {-month, } \\
6 \text {-month or } 12-\text {-month } \\
\text { continuous abstinence } \\
\text { (abstinent at the interview } \\
\text { with no smoking at all } \\
\text { after cessation); } 1 \text { month, } \\
6 \text { months and } 12 \text { months } \\
\text { Cotinine validation of } \\
\text { self-reported abstinence }\end{array}$ & $\begin{array}{l}\text { smoking cessation } \\
\text { outcomes. I, } 80 \% \text { vs } \\
79.8 \% \text { at } 1 \text { month } \\
\text { (NS). I, } 84.3 \% \text { vs UC, } \\
82.6 \% \text { at } 6 \text { months } \\
\text { (NS). I, } 91.4 \% \text { vs UC, } \\
89.3 \% \text { at } 12 \text { months } \\
\text { (NS). I, } 69.4 \% \text { vs UC, } \\
76.2 \% \text { at } 1 \text { month } \\
\text { (NS). I, } 71.4 \% \text { vs UC, } \\
73.9 \% \text { at } 6 \text { months } \\
\text { (NS). I, } 69 \% \text { vs UC, } \\
78.6 \% \text { at } 12 \text { months } \\
\text { (NS). I, } 69.4 \% \text { vs UC, } \\
75 \% \text { at } 1 \text { month (NS). } \\
\text { I, } 64.3 \% \text { vs UC, } 71 \% \\
\text { at } 6 \text { months (NS). I, } \\
63.8 \% \text { vs UC } 76.8 \% \text { at } \\
12 \text { months (NS). Urine } \\
\text { samples were } \\
\text { collected from } 83.8 \% \\
(258 \text { of } 308 \text { ) of } \\
\text { participants who } \\
\text { reported abstinence. } \\
\text { Cotinine validations } \\
\text { rates were } 85.6 \% \text { at } \\
1 \text { month, } 91.3 \% \text { at } \\
6 \text { months, } 89.6 \% \text { at } \\
12 \text { months }\end{array}$ & $\begin{array}{l}\text { smokers at baseline } \\
\mathrm{n}=96) \text {. Predictors of } \\
12-\text { month continuous } \\
\text { abstinence (applied to } \\
\text { the } 96 \text { baseline smokers } \\
\text { who completed the trial) }\end{array}$ & $\begin{array}{l}\text { study, from } 25.4 \text { cigarettes/ } \\
\text { day ( } \mathrm{SD}=12.8) \text { at baseline } \\
\text { to } 12.5(\mathrm{SD}=8.1) \text { at } \\
12 \text { months ( } \mathrm{t}=7.67 ; \\
\mathrm{p}=0.0001) \text {. No significant } \\
\text { difference between I and } \\
\text { UC participants. } \chi^{2} \text { of the } \\
\text { discrepancy between } \\
\text { larger number of } \\
\text { precontemplators in I group } \\
\text { and larger number of } \\
\text { participants in the action } \\
\text { stage of change in the } U \mathrm{C} \\
\text { group ( }(=0.017 \text { ) Stepwise } \\
\text { logistic regression; action } \\
\text { stage of change }(\mathrm{p}=0.0004) \\
\text { entered the model as } \\
\text { significant. }\end{array}$ \\
\hline
\end{tabular}


follow-up) and baseline readiness to change in the 96 patients who were classified as baseline smokers in their study $(p=0.002)$. Rates of continuous abstinence at 12-month follow-up were lowest for those in the precontemplation stage and highest for those in the action stage of change at baseline. No other smoking behaviours were reported as outcomes in the trial.

\section{DISCUSSION}

The objective of the present review was to examine the effectiveness of smoking cessation interventions to improve cessation rates in patients with HNC. Despite including both randomised and non-randomised trials, the review identified only three eligible studies. Of these, only one reported significant improvements in cessation rates at follow-up. These findings highlight the lack of robust smoking cessation intervention research conducted among patients with HNC, a group where ceasing tobacco use is particularly important.

All three studies employed interventions delivered by a health provider involved in the care of patients with HNC. Health professionals in the oncology setting are well positioned to deliver smoking cessation interventions and indeed numerous best practice guidelines recommend that those involved in the care of patients with cancer assess smoking status and offer support to quit. ${ }^{29}$ Interestingly, however, trials testing (1) nurse and physician brief advice to quit and information booklets combined with pharmacotherapy; and (2) surgeon delivered enhanced advice to quit smoking augmented by booster sessions were ineffective. Such findings are consistent with previous trials and reviews of physician-administered and nurse-administered interventions for patients with cancer who have found that relatively brief interventions are ineffective. ${ }^{29-31}$ Patients with smoking-related cancers generally have high levels of nicotine dependence, which affects quitting success. ${ }^{29}{ }^{32}$ More intensive smoking cessation interventions may be required to improve quit rates in this population.

Indeed, the only study in this review to find statistically significant differences between intervention and control groups on the primary cessation outcome was Duffy et $a l^{4}{ }^{4}$ The intervention used in this study was high intensity and multicomponent, with up to 11 telephone counselling sessions that targeted multiple risk behaviours with CBT and pharmacotherapy. This finding suggests that low-intensity or single intervention components that are sufficient for other patient groups may not be adequate to achieve cessation among patients with $\mathrm{HNC}$ characterised by long histories of heavy smoking and high nicotine dependence. ${ }^{33} 34$ Smoking cessation research in hospitalised patients has found that intensive smoking cessation interventions combining behavioural interventions with cessation medication maximise the likelihood of a positive long-term cessation outcome. ${ }^{35-37}$ Further trials of smoking cessation interventions in patients with HNC are needed to test this hypothesis, specifically randomised comparisons of long-term biochemically verified smoking cessation outcomes between patients receiving high-intensity, combined behavioural intervention and pharmacotherapy with low-intensity single component interventions.

Our finding also fits with the results of previous research that integrated treatment is effective for coexisting problems. ${ }^{16} 3839$ The health behaviours of patients with HNC, particularly smoking and drinking, are highly inter-related. A large proportion of patients with $\mathrm{HNC}$ who smoke also have a history of regularly consuming alcohol. ${ }^{21}$ Difficulties with nutrition due to the malignancy and treatment have been associated with smoking and problem drinking in $\mathrm{HNC}^{40}$ Given the co-occurrence of these behaviours in addition to the high rate of depression found in this group, addressing the interaction between smoking, drinking and depression in patients with HNC may be more beneficial for smoking cessation outcomes than targeted smoking treatment that ignores these other factors. The authors would cautiously suggest that multicomponent and integrated treatment be clinically recommended where available, while the evidence base is improved.

An important limitation of the review was the quality of studies included. Two studies received a methodological rating of weak and one received a rating of moderate. Although two of the three studies used a RCT design, the sample sizes were relatively small with the number of participants below 200 for all three studies. Only Gritz et $a l^{15}{ }^{28}$ confirmed smoking cessation status with biochemical verification. Biochemical verification of smoking status is recommended in studies of smoking cessation in medical populations with smoking related diseases. ${ }^{41}$ Research suggests that biochemical verification of current smoking status among patients with cancer can be as much as $20 \%$ higher than selfreport. ${ }^{42}{ }^{43}$ As such, the cessation outcomes reported in the included trials may represent an overestimate. Additionally, varying interventions, outcomes and end points, as well as the limited number of studies, precluded quantitative synthesis of the trial findings. While the review methods were based on the Cochrane handbook, the search was restricted to English language peerreviewed publications. In doing so, the review may not have captured all relevant studies in the field.

\section{CONCLUSIONS}

There are very few studies evaluating the effectiveness of smoking cessation interventions that report results specific to the HNC population. The results of this review indicate that a multicomponent approach may benefit patients with HNC who continue to smoke after diagnosis. However, this finding is based on one study, and therefore the current state of evidence does not allow for a recommendation of any specific form of smoking cessation treatment, in particular for this cancer group. There is much scope for developing the evidence base 
in this area. Given the significance of tobacco smoking as a key risk factor for HNC and its impact on treatment outcomes and further disease, it is imperative that further studies with strong methodological quality and standardised outcome measures are conducted in this population to guide development of smoking cessation programmes.

Contributors KM and UM conceptualised the review with input from $B B, A B e$, LW, CW, ABa, AG, SH and GC. KM and UM conducted screening, data extraction and methodological quality analysis. KM and UM drafted the manuscript. All authors contributed to subsequent drafts and have approved the final version of the manuscript.

Funding This work was supported by a Hunter Cancer Research Alliance Implementation Flagship Program grant. UM was supported by a grant from Fundación Barrié. BB is supported by a National Health and Medical Research Council Career Development Fellowship (GNT1063206) and a Faculty of Health and Medicine, University of Newcastle Gladys M Brawn Career Development Fellowship. LW is supported by a National Health and Medical Research Council Career Development Fellowship (GNT1063206) and a Faculty of Health and Medicine, University of Newcastle Gladys M Brawn Career Development Fellowship.

Competing interests None declared.

Provenance and peer review Not commissioned; externally peer reviewed.

Data sharing statement No additional data are available.

Open Access This is an Open Access article distributed in accordance with the Creative Commons Attribution Non Commercial (CC BY-NC 4.0) license, which permits others to distribute, remix, adapt, build upon this work noncommercially, and license their derivative works on different terms, provided the original work is properly cited and the use is non-commercial. See: http:// creativecommons.org/licenses/by-nc/4.0/

\section{REFERENCES}

1. Adelstein DJ, Ridge JA, Gillison ML, et al. Head and neck squamous cell cancer and the human papillomavirus: summary of a National Cancer Institute State of the Science Meeting, November 9-10, 2008, Washington, D.C. Head Neck 2009;31:1393-422.

2. Curado MP, Boyle P. Epidemiology of head and neck squamous cell carcinoma not related to tobacco or alcohol. Curr Opin Oncol 2013;25:229-34.

3. Huang SH, Xu W, Waldron J, et al. Refining American Joint Committee on Cancer/Union for International Cancer Control TNM stage and prognostic groups for human papillomavirus-related oropharyngeal carcinomas. J Clin Oncol 2015;33:836-45.

4. Duffy SA, Ronis DL, Valenstein M, et al. A tailored smoking, alcohol, and depression intervention for head and neck cancer patients. Cancer Epidemiol Biomarkers Prev 2006;15:2203-8.

5. Browman GP, Wong G, Hodson I, et al. Influence of cigarette smoking on the efficacy of radiation therapy in head and neck cancer. N Engl J Med 1993;328:159-63.

6. Chan Y, Irish JC, Wood SJ, et al. Smoking cessation in patients diagnosed with head and neck cancer. J Otolaryngol 2004;33:75-81.

7. Do K-A, Johnson MM, Doherty DA, et al. Second primary tumors in patients with upper aerodigestive tract cancers: joint effects of smoking and alcohol. Cancer Causes Control 2003;14:131-8.

8. Parsons A, Daley A, Begh R, et al. Influence of smoking cessation after diagnosis of early stage lung cancer on prognosis: systematic review of observational studies with meta-analysis. BMJ 2010;340: b5569.

9. Sitas F, Weber MF, Egger S, et al. Smoking cessation after cancer. $J$ Clin Oncol 2014;32:3593-5.

10. Day GL, Blot WJ, Shore RE, et al. Second cancers following oral and pharyngeal cancer: patients' characteristics and survival patterns. Eur J Cancer Part B Oral Oncol 1994;30B:381-6.

11. International Agency for Research on Cancer. Reversal of risk after quitting smoking. Lyon, France: International Agency for Research on Cancer, 2007.
12. Baser S, Shannon VR, Eapen GA, et al. Smoking cessation after diagnosis of lung cancer is associated with a beneficial effect on performance status. Chest 2006;130: 1784-90.

13. Florou AN, Gkiozos IC, Tsagouli SK, et al. Clinical significance of smoking cessation in subjects with cancer: a 30-year review. Respir Care 2014:59:1924-36.

14. Anthonisen NR, Skeans MA, Wise RA, et al. The effects of a smoking cessation intervention on 14.5-year mortality: a randomized clinical trial. Ann Intern Med 2005;142:233-9.

15. Gritz ER, Carr CR, Rapkin D, et al. Predictors of long-term smoking cessation in head and neck cancer patients. Cancer Epidemiol Biomarkers Prev 1993;2:261-70.

16. Cooley ME, Lundin R, Murray L. Smoking cessation interventions in cancer care: opportunities for oncology nurses and nurse scientists. Annu Rev Nurs Res 2009;27:243-72.

17. Nayan S, Gupta MK, Sommer DD. Evaluating smoking cessation interventions and cessation rates in cancer patients: a systematic review and meta-analysis. ISRN Oncol 2011;2011:849023.

18. Gritz ER, Fingeret MC, Vidrine DJ, et al. Successes and failures of the teachable moment: smoking cessation in cancer patients. Cancer 2006;106:17-27.

19. Lees J. Incidence of weight loss in head and neck cancer patients on commencing radiotherapy treatment at a regional oncology centre. Eur J Cancer Care (Engl) 1999;8:133-6.

20. Potash AE, Karnell LH, Christensen AJ, et al. Continued alcohol use in patients with head and neck cancer. Head Neck 2010;32:905-12.

21. Vander Ark W, DiNardo LJ, Oliver DS. Factors affecting smoking cessation in patients with head and neck cancer. Laryngoscope 1997;107:888-92.

22. Sharp L, Johansson $\mathrm{H}$, Fagerström $\mathrm{K}$, et al. Smoking cessation among patients with head and neck cancer: cancer as a 'teachable moment'. Eur J Cancer Care (Engl) 2008;17:114-19.

23. Moher D, Liberati A, Tetzlaff J, et al. Preferred reporting items for systematic reviews and meta-analyses: the PRISMA statement. J Clin Epidemiol 2009;62:1006-12.

24. Higgins JP, Green S. Cochrane handbook for systematic reviews of interventions. Wiley Online Library, 2008.

25. Armijo-Olivo S, Stiles CR, Hagen NA, et al. Assessment of study quality for systematic reviews: a comparison of the Cochrane Collaboration Risk of Bias Tool and the Effective Public Health Practice Project Quality Assessment Tool: methodological research. $J$ Eval Clin Pract 2012;18:12-8.

26. Deeks JJ, Dinnes J, D'Amico R, et al. Evaluating non-randomised intervention studies. Health Technol Assess 2003;7:iii-x, 1-173.

27. Gosselin MH, Mahoney MC, Cummings KM, et al. Evaluation of an intervention to enhance the delivery of smoking cessation services to patients with cancer. J Cancer Educ 2011;26: 577-82.

28. Gritz ER, Carr CR, Rapkin DA, et al. A smoking cessation intervention for head and neck cancer patients: trial design, patient accrual, and characteristics. Cancer Epidemiol Biomarkers Prev 1991;1:67-73.

29. Duffy SA, Louzon SA, Gritz ER. Why do cancer patients smoke and what can providers do about it? Community Oncol 2012;9:344-52.

30. Schnoll RA, Zhang B, Rue M, et al. Brief physician-initiated quit-smoking strategies for clinical oncology settings: a trial coordinated by the Eastern Cooperative Oncology Group. J Clin Oncol 2003;21:355-65.

31. Griebel B, Wewers ME, Baker CA. The effectiveness of a nurse-managed minimal smoking-cessation intervention among hospitalized patients with cancer. Oncol Nurs Forum 1998;25:897-902.

32. McBride CM, Ostroff JS. Teachable moments for promoting smoking cessation: the context of cancer care and survivorship. Cancer Control 2003;10:325-33.

33. Almeida AÁ, Bandeira CM, Gonçalves AJ, et al. Nicotine dependence and smoking habits in patients with head and neck cancer. J Bras Pneumol 2014;40:286-93.

34. Sivasithamparam J, Visk CA, Cohen EE, et al. Modifiable risk behaviors in patients with head and neck cancer. Cancer 2013;119:2419-26.

35. Stead LF, Lancaster T. Combined pharmacotherapy and behavioural interventions for smoking cessation. Cochrane Database Syst Rev 2012;10:CD008286.

36. Wolfenden L, Campbell E, Walsh R, et al. Smoking cessation interventions for in-patients: a selective review with recommendations for hospital-based health professionals. Drug Alcohol Rev 2003;22:437-52. 
37. Wolfenden L, Campbell E, Wiggers J, et al. Helping hospital patients quit: what the evidence supports and what guidelines recommend. Prev Med 2008;46:346-57.

38. Baker AL, Kavanagh DJ, Kay-Lambkin FJ, et al. Randomized controlled trial of cognitive-behavioural therapy for coexisting depression and alcohol problems: short-term outcome. Addiction 2010;105:87-99.

39. Ait-Daoud N, Lynch WJ, Penberthy JK, et al. Treating smoking dependence in depressed alcoholics. Alcohol Res Health 2006;29:213-20.
40. Duffy SA, Khan MJ, Ronis DL, et al. Health behaviors of head and neck cancer patients the first year after diagnosis. Head Neck 2008;30:93-102.

41. Benowitz NL, Jacob lii $\mathrm{P}$, Ahijevych $\mathrm{K}$, et al. Biochemical verification of tobacco use and cessation. Nicotine Tob Res 2002;4:149-59.

42. Cooley ME, Sarna L, Brown JK, et al. Tobacco use in women with lung cancer. Ann Behav Med 2007;33:242-50.

43. Gariti $\mathrm{P}$, Rosenthal DI, Lindell K, et al. Validating a dipstick method for detecting recent smoking. Cancer Epidemiol Biomarkers Prev 2002;11(Pt 1):1123-5. 